


\title{
A METEOROLOGICAL STUDY OF PARKS AND TIMBERED AREAS IN THE WESTERN YELLOW-PINE FORESTS OF ARIZONA AND NEW MEXICO
}

\author{
G. A. PEARSON
}

FOREST EXAMINER 
SI 425

$P_{3}$

Copy 2 .

$$
\begin{gathered}
\text { D. OF D. } \\
\text { FEB } 21 \quad 1914 .
\end{gathered}
$$




\section{A METEOROLOGICAL STUDY OF PARKS AND TIMBERED AREAS IN THE WESTERN YELLOW-PINE FORESTS OF ARIZONA AND NEW MEXICO.}

By G. A. Pearson, Forest Examiner.

OBJECT OF THE STUDY.

The object of the study, the results of which are presented here, was to determine the influence of the forest cover upon climate locally in the Southwest, in so far as this influence might be of importance in the management of timberlands and the possible afforestation of parks and denuded areas.

Since the bearing upon forestry rather than upon meteorology is the primary consideration, comparatively little attention is given to purely meteorological problems. The study, moreover, makes no pretense of investigating the influence of the forest upon the general climate of the region. A study of the regional climatic influences would require more complete observations and an extended series of stations during a long period of years. Such observations have been made in Germany, Austria, Sweden, France, and other European countries, and have served as a foundation for the present study, although, as the results show, the relations found to exist between forest and field in Europe are in many cases greatly modified under the vastly different conditions prevailing in Arizona and New Mexico. A comprehensive review of European investigations in forest meteorology is included in Forest Service Bulletin No. 7, Part II, and in the final report of the National Waterways Commission, Senate Document 469.

THE REGION.

FOREST AND TOPOGRAPHY.

The locality in which this study was made lies well within the limits of a practically continuous belt of forest, from 25 to 100 miles in width, and extending from north central Arizona in a southeasterly direction into southwestern New Mexico, a distance of approximately 350 miles. In northern Arizona, where the study was made, the forest occupies an extensive plateau, known as the Colorado Plateau, which has a general elevation of from 6,000 to 8,000 feet above sea level, with numerous peaks, the highest nearly 13,000 feet. Western yellow-pine (Pinus ponderosa) occupies the level mesas and lower slopes from approximately 6,500 to 8,500 feet, forming a belt from 10 to 30 miles wide, which extends almost the entire length of the timbered area and constitutes the largest pine forest on the continent. The mountain slopes above 8,500 feet are covered mainly by Douglas fir (Pseudotsuga taxifolia), white fir (Abies concolor), limber pine (Pinus flexilis), bristle-cone pine (Pinus aristata), and Engelmann spruce (Picea engelmanni) Beginning at 6,500 feet and extending down to about 5,000 feet is a woodland forest, composed mainly of two junipers (Juniperus pachyphloea and Juniperus utahensis), piñon pine (Pinus edulis), together with several pieces of oak. The woodland forms a belt from 10 to 25 miles wide, which may be considered a transition zone between the timber forest and the treeless area below. These zones of forest growth are typical of the timber regions of Arizona and New Mexico; the altitudinal limits, however, vary considerably with latitude and local conditions.
CLIMATE.

The climate of this region, which is fairly typical of the higher altitudes of Arizona and New Mexico, is characterized by great daily ranges of temperature and very marked seasonal variations in precipitation, atmospheric moisture, and wind movement. The percentage of sunshine is very high. Owing to the excessive radiation characteristic of the high altitudes and dry climate in which the western yellow-pine forests occur, the change of temperature from day to night is usually very great, frequently amounting to more than $50^{\circ} \mathrm{F}$. Practically all of the precipitation, which in the western yellow-pine forest amounts to from 20 to 25 inches per year, falls during the summer and winter months, the former period extending approximately from July 1 to September 1, and the latter from December 1 to April 1. During the summer rainy season showers occur almost daily, and the relative humidity is usually high. During the winter months the precipitation comes mainly in the form of snow, which, in the higher altitudes of the western yellowpine forest, accumulates to the depth of 3 feet or more. As a rule there is practically no precipitation from about April 1 to July 1, and this period is characterized by extremely rapid evaporation and frequent high winds. It is exceedingly trying on regetation, especially forest seedlings which have not become well established. A similar, though usually much less severe, period of drouth and wind extends from about September 1 to November 1.

$$
\text { PARKS. }
$$

The western yellow-pine forests of the region grow naturally in very open stands. These usually consist of small groups from 50 to 100 feet or more in width, of mature or nearly mature trees, separated by groups of younger trees, sometimes seedlings, sometimes saplings, and sometimes poles. Frequently, however, there are openings bare of trees between the groups. These openings are usually several hundred yards wide, but occasionally they cover several square miles. Openings of the latter class are commonly known as "parks," or, if very large, they are sometimes called prairies.

A number of theories have been advanced in explanation of the origin of the parks in this region. One is that they were once timbered but have subsequently been denuded by fires. A more plausible theory in the case of most parks is that they are naturally treeless, owing to the presence of conditions unfavorable to tree growth.

\section{THE FORT VALLEY PARE.}

The park selected for this study lies about 8 miles northwest of the town of Flagstaff, on the Coconino National Forest, and is locally known as Fort Valley. It is approximately $1 \frac{1}{2}$ miles wide by $2 \frac{1}{2}$ miles long, the major diameter extending from northeast to southwest. (See fig. 1.) The topography is practically level, and the average elevation is approximately 7,250 feet. The soil is mainly a gravelly alluvial loam underlain at depths ranging from 1 to 3 feet by deposits of volcanic cinders. About two-thirds of the land is under cultivation and the re- 


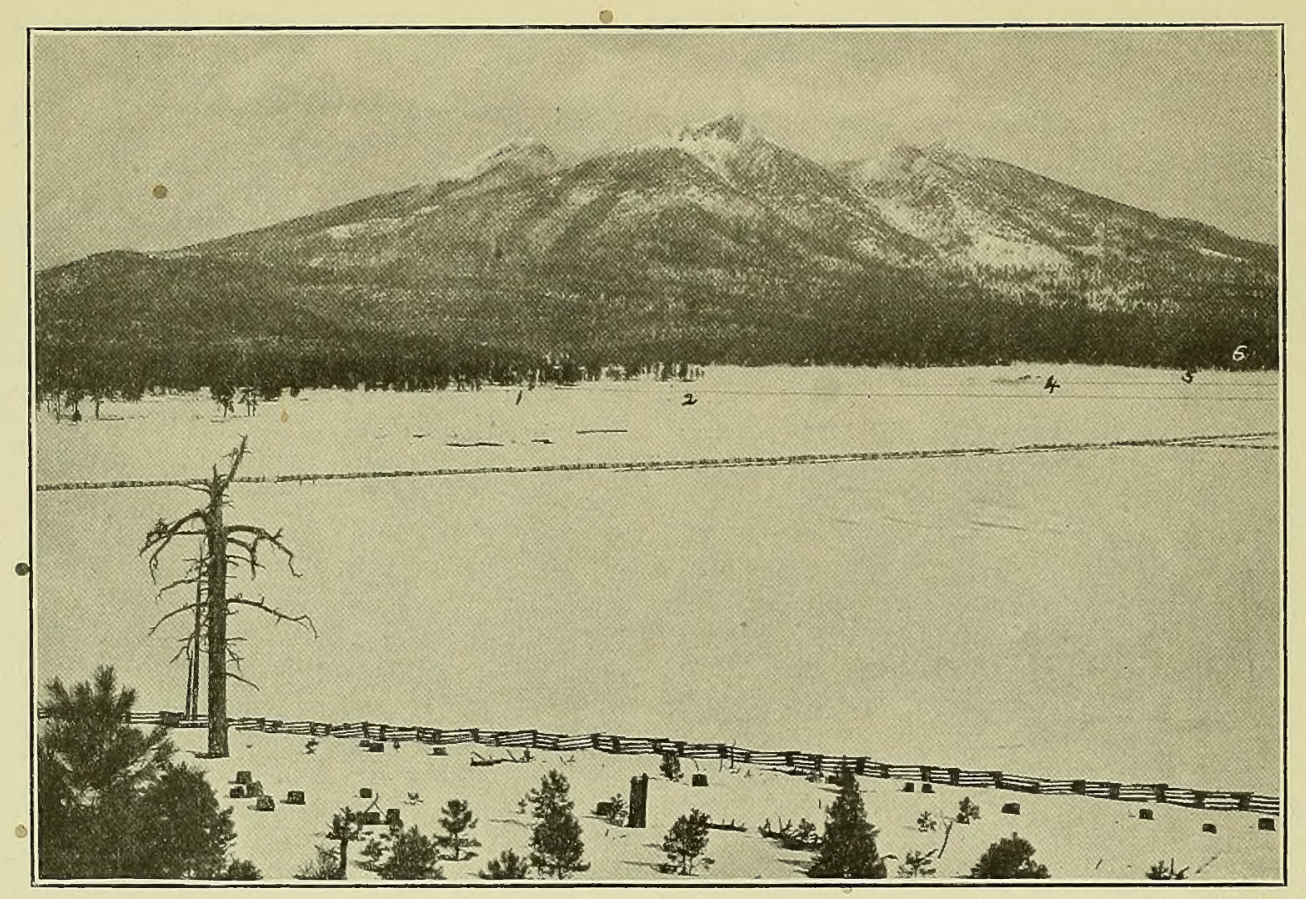

Fis. 1.-Fort Valley Park, looking toward the San Francisco Mountains. The figures indicate the location of meteorological stations.

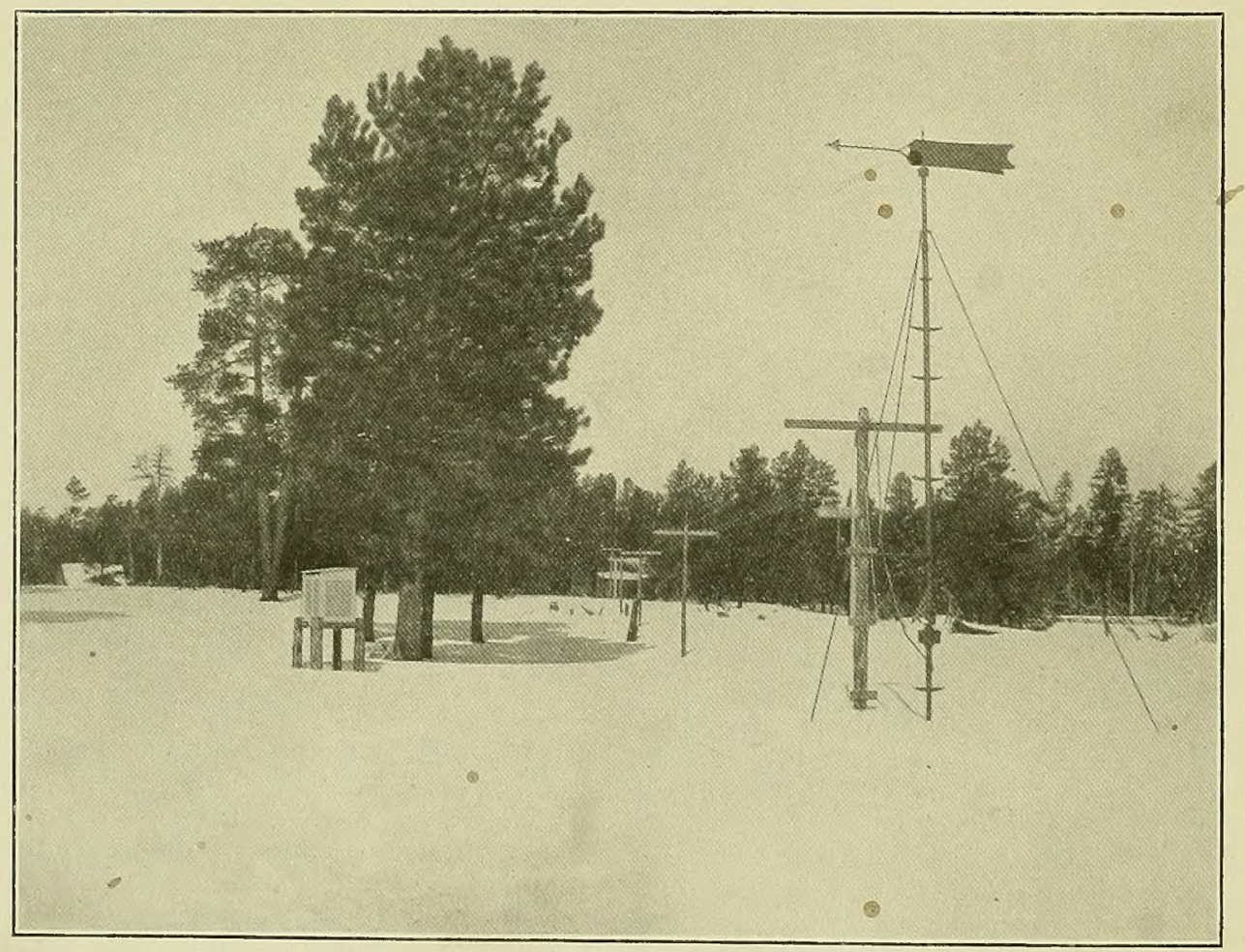

FIG. 2,-Meteorological station No. 1, edge of forest. 


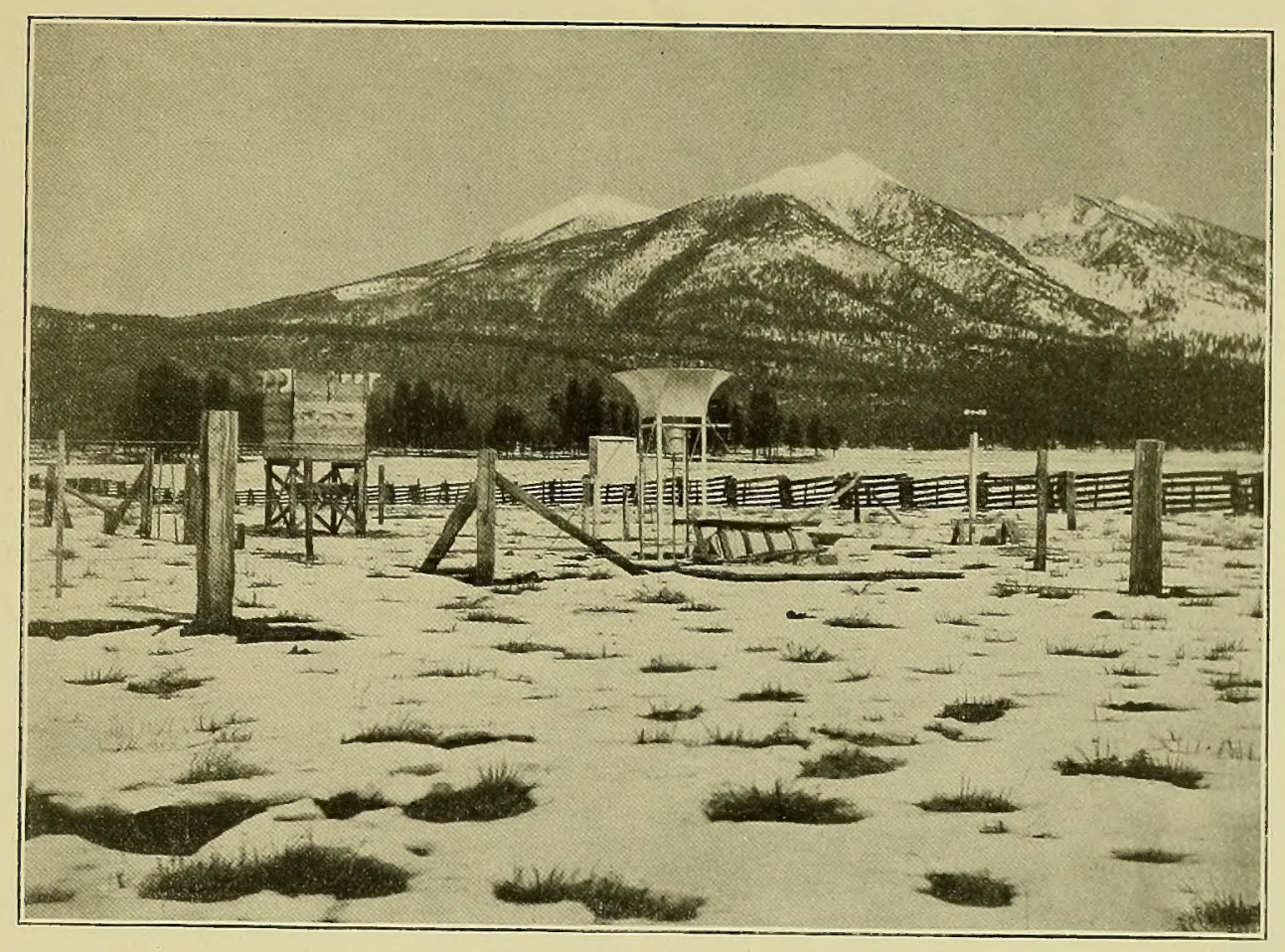

FIG. 3.-Meteorological station No. 2,Ipark.

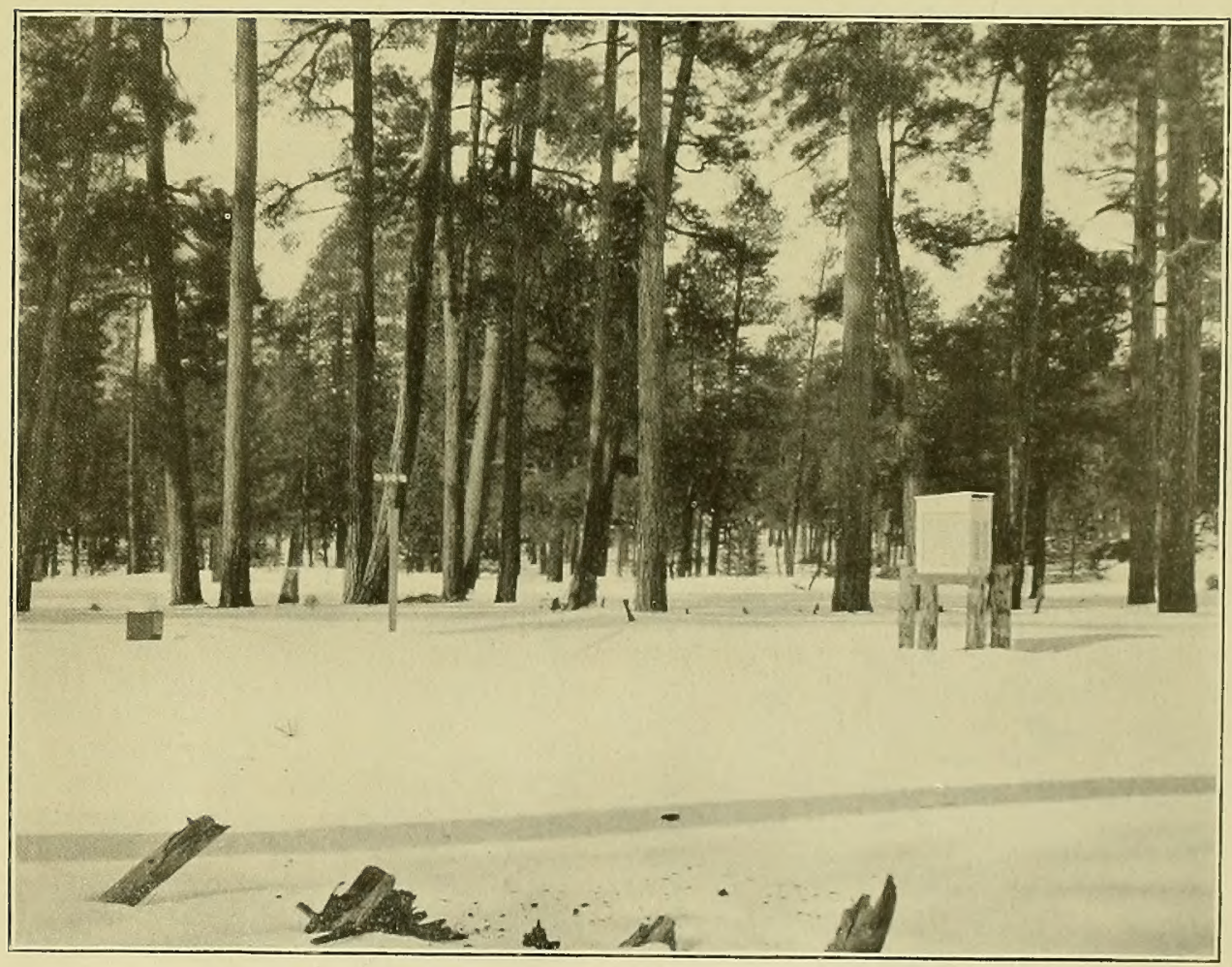

FIG. 4.-Meteorological station No. 3, forest. 
mainder is covered by a fairly dense growth of gramma grass (Bouteloua oligostachya). A moderately heavy forest of western yellow-pine, opened here and there by light cuttings, surrounds the park. The timber almost invariably occurs at a slightly higher elevation than the adjacent park land. In some places the timbered area rises from the edge of the park on a very gentle slope, while in others there is a rather abrupt rise of from 25 to 100 feet. Occasional narrow, slightly elevated tongues of timbered land extend out into the opening a distance of as much as one-fourth mile, and in two instances small isolated patches of saplings occur on slight eminences well out in the park.

The park and the immediately surrounding timbered areas present the appearance of a partial basin. From 3 to 4 miles to the north and east of the park begin the steep slopes of the San Francisco Mountains which, in a horizontal distance of 3 or 4 miles, rise from an elevation of 8,500 feet to 12,340 feet, or approximately 5,000 feet above the level of the Fort Valley Park. Minor peaks in the near vicinity are Wing Mountain, about 2 miles northwest, and Crater Mountain, bordering on the south edge of the park, with elevations of 8,500 and 8,300 feet, respectively. About 6 miles to the southeast, practically connected with the San Francisco Mountains by a series of spurs and ridges, is Elden Mountain, with an elevation of 9,280 feet. On the south and west sides the steep timbered slopes rise from 200 to 300 feet above the park into a level mesa, which here forms the rim of the basin.

\section{METEOROLOGICAL OBSERVATIONS.}

The meteorological observations at Fort Valley were conducted at six "parallel" stations, extending in a chain from the timber on the west side of the park across the park into the timber on the east side. Continuous records have been kept only at the three stations on the west side of the park. Daily readings of temperature, precipitation, relative humidity, and wind movement have been made since January 1, 1909, at these three stations, one of which is well out in the park, one in the edge of the timber, and one about one-fourth of a mile in the forest. Soil temperature and evaporation readings have been made during the growing season. Additional observations of temperature were taken from January 25 to February 18 near the middle and east edge of the park, and about one-fourth of a mile back in the timber to the east.

LOCATION AND EQUIPMENT OF METEOROLOGICAL STATIONS.

Station 1 is located on the edge of a projecting point of timber on the west side of the park, at an elevation of 7,261 feet. The station is equipped with a set of maximum and minimum thermometers, a psychrometer, an anemometer, a wind vane, a standard rain gage and an evaporation pan. The wind instruments and rain gage are connected with an automatic register, which gives a continuous record of wind movement, wind direction, and rainfall. This station is protected on the west and northwest sides, but receives the full force of the wind from other directions, especially the southwest, which is the prevailing wind direction in this region. The ground cover here, as at the park stations, is mainly gramma grass.

Station 2 is situated in the park, 840 feet southeast of station 1, at an elevation of 7,247 feet. The equipment consists of a set of maximum and minimum thermometers, a psychrometer, an anemometer, a shielded rain gage, and an evaporation pan.

Station 3 is in a virgin stand of western yellow-pine, 1,453 feet west from the edge of the park, at an elevation of 7,348 feet. The soil at this station, as at Forest station 6 , is a reddish clayey loam, mixed with gravel and large volcanic bowlders. The ground cover consists of a sparse growth of grasses and other herbs. Practically no leaf litter is found beyond 30 feet from the trees. The instruments are set in an opening 160 feet in diameter, and are 60 feet from the nearest trees. The equipment is the same as for station 2, excepting that a standard rain gage is used.

Stations 4,5 , and 6 are temporary stations at which only records of temperature have been made.

Station 4 is very near the middle of the park, $1 \frac{1}{2}$ miles almost due east from station 2 , at an elevation of 7,246 feet. The equipment consists of a set of maximum and minimum thermometers.

Station 5 is in the park, 725 feet west from the west edge of the forest, at an elevation of 7,264 feet. The equipment consists of a thermograph and a set of maximum and minimum thermometers.

Station 6 is in a virgin stand of western yellow pine, 1,617 feet northeast from the east edge of the park, at an elevation of 7,330 feet. There is a gradual slope of about $2^{\circ}$ from station 6 to station 5 , the distance between the two stations being 2,300 feet. The equipment is the same as that of station 5 .

All of the stations were located with the view of securing normal atmospheric drainage.

\section{INSTRUMENTS AND METHODS OF OBSERVATION.}

All of the instruments are of the standard United States Weather Bureau type, installed and operated under the direction of this bureau. Since it is especially desired to determine the atmospheric conditions to which seedling growth is exposed the instruments have in most cases been placed nearer the ground than is the usual practice of the Weather Bureau. It has been necessary, however, to place them at a sufficient height to avoid their being covered by snow, which in this locality may reach a depth of 3 feet or more.

The thermometers at the permanent stations are exposed in the standard United States Weather Bureau shelter, but at the temporary stations they are exposed in improvised wooden boxes open on the north side. All of the shelters were originally placed with the floor 4 feet above the ground, thus bringing the thermometers to a height of $5 \frac{1}{2}$ feet. On August 13, 1912, the shelters at stations 2 and 3 were raised so as to place the thermometers at 8 feet. The reasons for, and the effect of, this change are discussed under Results of Observations.

The anemometers are placed 8 feet above the ground.

The evaporation pans are 10 inches in depth and about 3 feet in diameter. They were set in a level position on top of the ground. By frequent fillings the water was kept as nearly as possible at a constant level in all three pans. The depth of the water was measured weekly and from this the loss by evaporation was computed, after making the proper allowance for rainfall.

After the first year rainfall records for the purpose of comparing forest and park were taken only at stations 1 and 3 , since a different type of rain gage was used at station 2. Snowfall has been measured by taking the average depth on the ground at 10 permanent stakes 
near stations 2 and 3 . On account of the short distance between stations 1 and 2 , and the similarity of exposure, there is practically no difference in the precipitation at these points, as shown by the records of 1909. For this reason the rainfall records at station 1 , and the snowfall records at station 2 have been combined to give the total precipitation of the park.

The instruments at the permanent stations were read daily between 4 and 5 o'clock $\mathrm{p}$. $\mathrm{m}$. during the first two years. For the sake of convenience the time of reading was changed to between 8 and 9 a. m. in 1911. Since, with the exception of relative humidity, the readings indicate the totals or extremes for the period between readings rather than current conditions, relative humidity is the only factor affected by the change. The temporary stations 4,5 , and 6 , on account of their distance from headquarters, were visited only at intervals of from two to four days. The use of thermographs made it possible to secure continuous records at stations 5 and 6 . The readings from the maximum and minimum thermometers served as a check upon the accuracy of the thermographs, and made it possible by interpolation to reduce the errors in the thermograph records in most cases to less than 1 degree. The records at station 4 , since it was not provided with a thermograph and could not be visited daily, are badly broken, but furnish a rough comparison of conditions in the middle of the park with those in other situations.

\section{RESULTS OF OBSERVATIONS.}

\section{AIR TEMPERATURE.}

Table 1 gives a monthly summary of the temperature records at stations 1,2 , and 3 during the four years, 1909-1912. A graphic comparison of the mean maximum, mean minimum, and mean (mean maximum + mean minimum $\div 2$ ) at stations 2 and 3 is given in figure 5.

TABLE 1.-Temperature in forest, edge of forest, and park, by months, 1909-1912.

TEMPERATURE.

\begin{tabular}{|c|c|c|c|c|c|c|c|c|c|}
\hline \multirow[b]{2}{*}{$1909-1912$} & \multicolumn{3}{|c|}{ Forest (Station 3) ${ }^{1}$} & \multicolumn{3}{|c|}{ Edge Forest (Station 1). } & \multicolumn{3}{|c|}{ Park (Station 2).1 } \\
\hline & $\begin{array}{l}\text { Mean } \\
\text { maxi- } \\
\text { mum. }\end{array}$ & $\begin{array}{l}\text { Mean } \\
\text { mini- } \\
\text { mum. }\end{array}$ & Mean.2 & $\begin{array}{l}\text { Mean } \\
\text { maxi- } \\
\text { mum. }\end{array}$ & $\begin{array}{l}\text { Mern } \\
\text { mini- } \\
\text { mum. }\end{array}$ & Mean. & $\begin{array}{l}\text { Mean } \\
\text { maxi- } \\
\text { mum. }\end{array}$ & $\begin{array}{l}\text { Mean } \\
\text { mini- } \\
\text { mum. }\end{array}$ & Mean. \\
\hline & - $F$ & $\circ F$ & ${ }^{\circ} F$ & - $F$ & ${ }^{\circ} F$ & $\circ F$ & - $F$ & $F$ & ${ }^{\circ} F$ \\
\hline $\begin{array}{l}\text { January... } \\
\text { February. }\end{array}$ & $\begin{array}{l}41.9 \\
41.9\end{array}$ & $\begin{array}{l}16.6 \\
15.4\end{array}$ & $\begin{array}{l}29.2 \\
28.6\end{array}$ & $\begin{array}{l}42.1 \\
42.6\end{array}$ & $\begin{array}{r}10.6 \\
9.7\end{array}$ & $\begin{array}{l}26.3 \\
26.1\end{array}$ & $\begin{array}{l}42.9 \\
42.8\end{array}$ & $\begin{array}{r}10.3 \\
8.1\end{array}$ & $\begin{array}{l}26.6 \\
25.4\end{array}$ \\
\hline March. & 17.3 & 22. & 34 . & 46 & 19. & 32.9 & 47. & 17.0 & 32.2 \\
\hline A pril. & 53.7 & 25.7 & 39.7 & 55. & 22 . & 39 & 55 & 21 & 38,4 \\
\hline Мау. & 65. & 31 . & 48. & 66 & 27. & 47.1 & 66. & 25.1 & 45.9 \\
\hline & 75. & 39 . & 57. & 76 & 35. & 55 & 76 & 31 & 54.0 \\
\hline July. & 76. & 47.8 & 62. & 76. & 45.5 & 61.1 & 76 & 43. & 59.8 \\
\hline Augu & 75. & 47. & 61. & 75 & 44 & 60. & 75. & 42. & 59.1 \\
\hline Septe & 70. & 40. & 55 & 70 & 35 & 53 & 71 & 33. & 52.3 \\
\hline October... & 60. & 29. & 44. & 60. & 25. & 42. & 61. & 22.9 & 42.3 \\
\hline Noven & 52. & 21. & 36 & 52. & 17. & 35.0 & 53. & 15.0 & 34.1 \\
\hline December. & 39.6 & 11.1 & 25.3 & 40.3 & 5.5 & 22.9 & 40.8 & 2.6 & 21.7 \\
\hline A $\mathbf{n}$ m $u$ a 1 & 58.3 & 29.1 & 43.7 & 58.9 & 24.8 & 41.8 & 59.2 & 22.7 & 41.0 \\
\hline
\end{tabular}

1 The thermometers at stations 2 and 3 were raised from $5 \frac{x}{2}$ to 8 feet on Aug. 13, 1912 . 2 Mean maximum + mean minimum divided by 2 .

In order to determine whether the temperature relation between stations 1,2 , and 3 was normal for the park and forest of the vicinity, temperature readings were taken at three additional stations $(4,5$, and 6$)$ from January 26 to February 18.

Figures 6 and 7 compare graphically the current temperature at forest station 3 and park station 2 during the weeks beginning December 24, 1909, and January 14, 1910, respectively. These curves are exact tracings from thermograph records.

A comparison of the monthly averages as given in Table 1 and graphically represented in figure 5 shows a slightly lower mean maximum, a decided higher mean, and a very much higher mean minimum in the forest than in the park.

The lower maximum temperature in the forest may be attributed to lower insolation, less circulation of the air, and the cooling effect resulting from transpiration from the tree foliage. The difference in maximum temperatures appears to be greatest during periods of clear, dry, weather, notably in April and May and in October and November, and least during periods of cloudy weather, particularly during the rainy season of July and August. Probably the greatest factor in determining this difference is the presence of clouds, since under a clouded sky the shade of the trees would have a minimum effect. Measurements of the total solar radiation received near the ground would undoubtedly show a much greater difference than do the air temperatures. This is strikingly illustrated by the soil temperature (Table 4) which, despite the higher mean air temperature in the park, is $5^{\circ}$ lower in the forest, at a depth of 2 feet, than in the park. At a depth of 1 inch the temperature of the soil exposed to the sun was found to be $140^{\circ}$, when in the shade of a group of trees near by it was only $87^{\circ}$.

Another factor which may influence the relation between forest and park maxima is wind. The periods of dry, clear weather are also periods of high winds, which even in the forest promote a thorough diffusion of atmospheric heat. But in the rainy seasons, particularly in July and August when the wind is very low, the air in the forest, where the wind movement is much less than in the park, frequently becomes stagnant, with the result that the current temperature at the forest station may be higher than at the park station.

Since the extremes of forest and park temperatures tend to neutralize one another - that is the maximum in the park is higher and the minimum lower than in the forest-mean temperature is a poor indicator of the actual conditions. It is in the tempering of extremes, particularly the minimum, that the difference between forest and park makes itself felt. As pointed out under "Climate," the fluctuation between day and night temperature is enormous. This is true of the park much more than of the forest. It is common in clear weather to find the minimum temperature in the forest $10^{\circ}$ or $12^{\circ}$ higher than in the park, and occasionally the difference is more than $20^{\circ}$.

The relation between current as well as extreme temperatures in forest and park is strikingly illustrated by the thermograph records in figures 6 and 7 . The curves for the forest show, in addition to a much smaller daily range, less pronounced minor fluctuations and a more gradual change from one extreme to the other. As indicated on the sheets, the curves in figure 6 cover a period of practically clear days, while those in figure 7 cover a period of both clear and cloudy days. Figure 7 shows that the curves for forest and park are practically identical in cloudy weather, a similarity which is characteristic throughout the year. The differences between the records of the forest and the park, in clear weather, are less pronounced during the summer time than during the winter time.

Since it was suspected that the great difference between the minimum temperature of the forest and park might be due to ground influence, owing to the fact that 


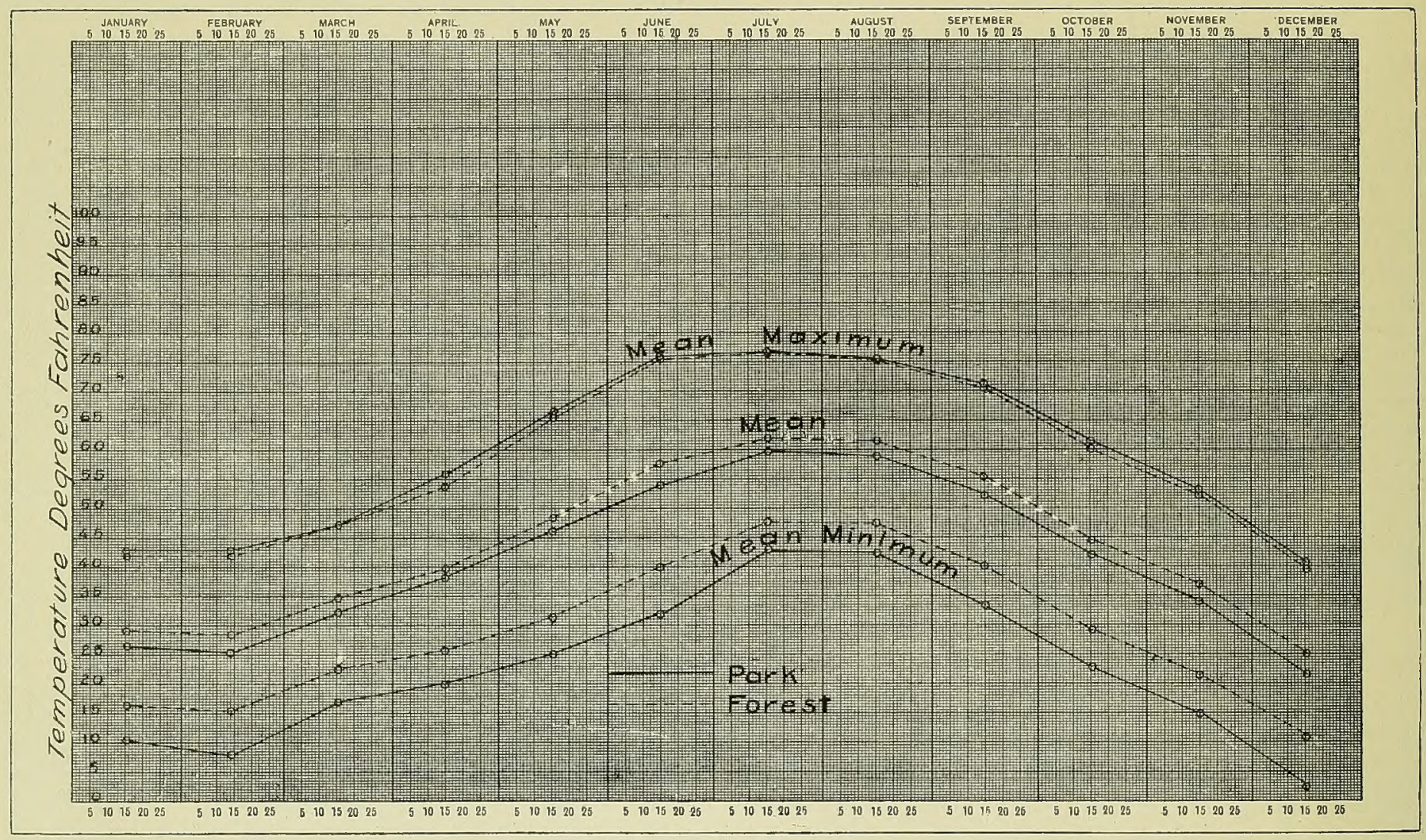

FIG. 5.

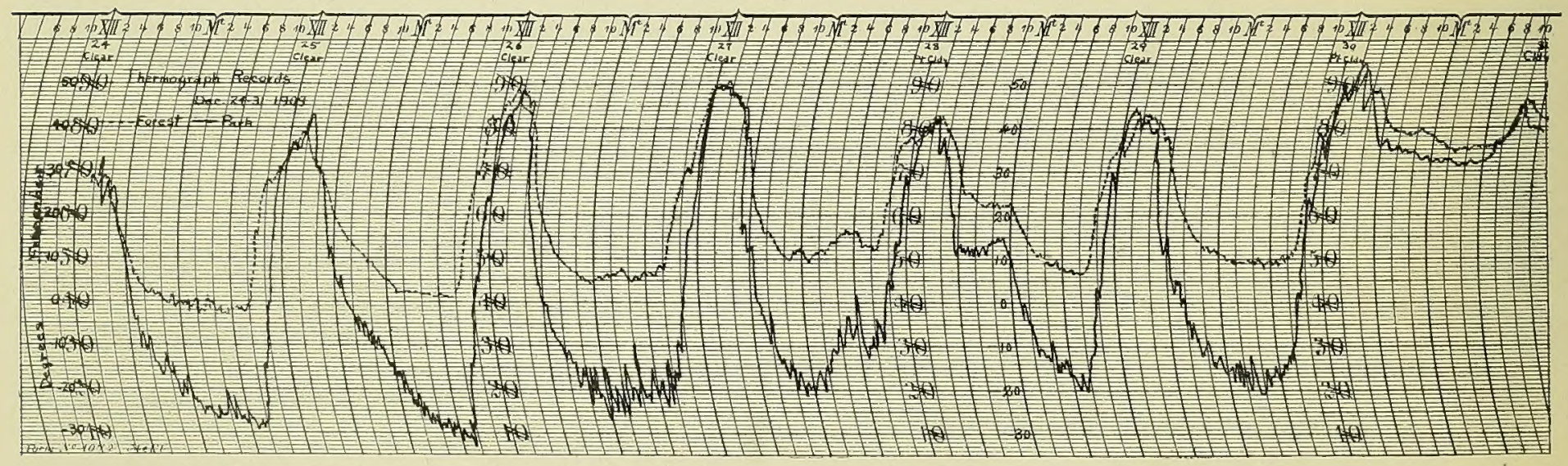

FIG. 6. 


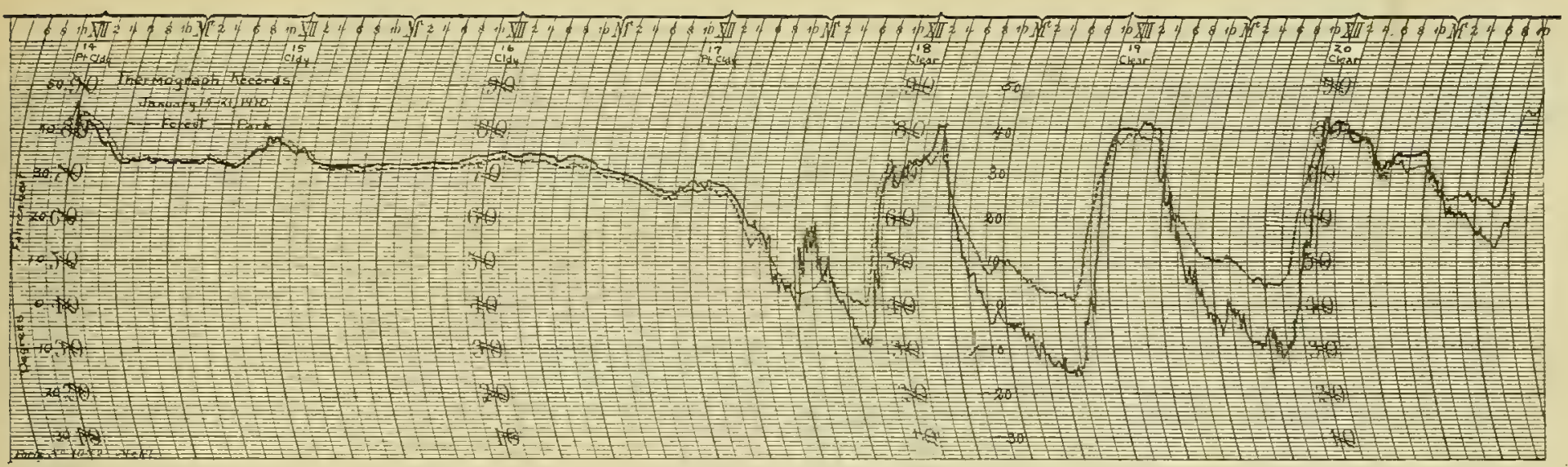

FIG. 7.

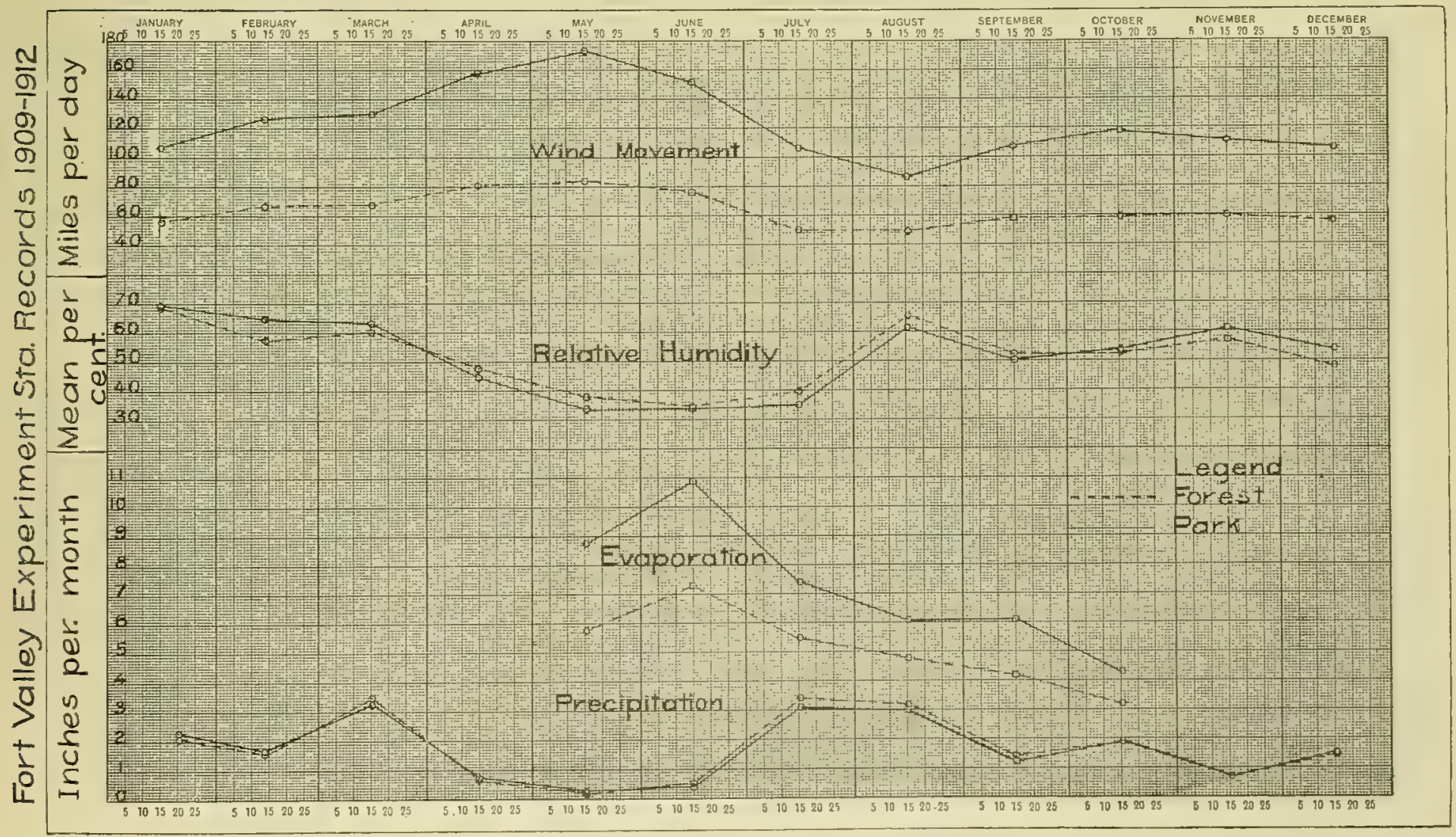

FIG. 8. 
the shelters were placed only 4 feet above the ground, a second set of maximum and minimum thermometers was exposed at station 2 in a shelter placed at $6 \frac{1}{2}$ feet above the ground during the months of June and July, 1912. A comparison of the monthly average at the two elevations ${ }^{1}$ follows:

TABLE 2.-Temperature at different heights above the ground.

\begin{tabular}{|c|c|c|c|c|c|c|}
\hline & ALean $I$ & ximum. & Mean n & limum. & & \\
\hline & $5_{2}^{1}$ feet. & 8 feet. & $5 \frac{1}{2}$ feet. & 8 feet. & 5 t feet. & 8 feet. \\
\hline $\begin{array}{l}\text { June } \\
\text { July }\end{array}$ & $\begin{array}{l}{ }^{\circ} F \\
74.9 \\
73.6\end{array}$ & $\begin{array}{l}{ }^{\circ}{ }_{1} \\
74.2 \\
73.1\end{array}$ & $\begin{array}{l}{ }^{\circ} F \\
32.7 \\
40.1\end{array}$ & $\begin{array}{r}{ }^{\circ} F \\
34.9 \\
42.0\end{array}$ & $\begin{array}{l}{ }^{\circ} F . \\
53.8 \\
56.8\end{array}$ & $\begin{array}{r}{ }^{\circ} F_{5} \\
54.5 \\
57.5\end{array}$ \\
\hline
\end{tabular}

As was to be expected, the results in both months show a reduction of the range, due mainly to the higher minimum, at 8 feet; but the difference is not sufficient to warrant the opinion that the past records in the park are abnormal. On August 13, the shelter at station 3 also was raised to $6 \frac{1}{2}$ feet. A comparison of the records at stations 2 and 3 before and after the shelters were raised discloses no material change in the relations.

Since the relative rather than absolute temperatures in forest and park are considered the important thing in this study, it has not been considered necessary to reduce the readings, before and after raising the thermometers, to the same basis. This should be considered in comparing stations 2 and 3 with station 1 , but since the temperature at station 1 is not regarded as typical of either forest or park, it has not been considered in this discussion.

The temperature at station 1 in the edge of the forest usually lies between that of the forest and that of the park station, but approaches the latter very closely.

The records of the temporary stations 4,5 , and 6 indicate practically the same relation between forest and park temperatures as that found at the permanent stations 2 and 3, excepting for the maximum temperature, which at the temporary stations is higher in the forest than in the park, while at the permanent stations it is lower in the forest than in the park. A comparison of the records at the six stations show that with respect to the mean and minimum temperatures, at least, the conditions indicated by the permanent stations may be considered as fairly normal for this locality.

A comparison of the above results with European observations is interesting.

At stations in Europe similarly located in regard to the forest, as at the Fort Valley Experiment Station, the maximum is lower and the minimum higher in the forest than in the open; thus the general effect, that of mitigating the extremes, is the same. The difference is that at the European stations the maximum is lowered more than the minimum is raised, while at this station the minimum is raised more than, the maximum is lowerd, with the result that at the European stations the mean temperature of the forest is lower than that in the open, while at this station the reverse is true. The greater decrease of the maximum temperature in the European forests is probably explained by the fact that their forests are much denser than ours, thus affording more shade and a greater cooling effect, due to the transpiration from the foliage. The greater density of the European forests 1 The floors of the shelters are 4 and $6 \frac{1}{2}$ feet, respectively, above the ground, but the
thermometers are about 18 inches higher, making the actual height $5 \frac{1}{2}$ and 8 feet, respecthermornety.
tively. would also be expected to produce a greater effect upon the minimum there than at this station, but this is not the case. It is probable that the tremendous difference in the minimum temperatures of the forest and park at Fort Valley is due partly to other causes, which will be discussed later.

In seeking to account for the great difference between the minimum temperatures of the forest and the park the first factor to suggest itself is the difference in radiation. The change of temperature from day to night, owing to the excessive rate of radiation in the rare atmosphere of this altitude, combined with the low atmospheric moisture, is usually very great. It is therefore possible that the tree crowns might exert a retarding influence upon the loss of heat sufficient to noticeably affect the temperature of the forest. This opinion is supported by the fact that in clnudy weather when radiation is reduced to a minimum, the lowest temperatures recorded in the timber are usually about the same as those recorded in the park, and on the edge of the forest, as shown by the thermograph curves in figure 7 . It has been determined by instrumental observations that on clear nights the temperature under a cover of branches near the ground is several degrees higher than that of a near-by open place. Observations have also shown that seedlings under a cover of branches are less susceptible to injury from frost than seedlings on an adjacent open plot. But, while there is little doubt that the tree crowns do exert a retarding effect upon radiation, yet when we consider that in the western yellow-pine forest the trees actually cover not much more than one-half of the total area, and that in this investigation the forest stations are placed in small openings instead of directly underneath the trees, it seems doubtful whether the effect of the crowns would be sufficient to account for the great differences which have been recorded.

The enormous difference between the minimum temperatures of the forest and park stations suggest the existence of influences other than that of the forest cover. Increased atmospheric moisture in the forest would have a tendency to check radiation, and thereby keep the minimum higher, but unfortunately the available data on atmospheric moisture are not sufficient to prove whether or not it is greater in the forest than in the open.

The fact that the park is slightly below the level of the surrounding timbered areas suggests the idea that the cold air of the vicinity settles into the park, thereby redueing the temperature below normal. To throw light on this question, a comparison of temperatures was made between a virgin forest and an adjacent cut-over area of equal elevation during a period of almost three months, from October 1 to December 25, 1910. The place selected for this study is about 4 miles southwest of Flagstaff, at an altitude of approximately 7,100 feet. The forest station is in a solid section of virgin western yellow-pine, about one-fourth mile from the east line, which is the nearest exposure to nonforested conditions. The station on the cut-over area is about one-fourth mile east of the edge of the forest, surrounded by a seattering of trees left by the lumberman. Both the forest and the eut-over land have a gently rolling topography, and lie on the same level as the surrounding region. On both areas the instruments were set on slight rises, to insure normal air drainage.

The records at both stations were secured by means of Richards's thermographs exposed in United States Weather Burcau shelters placed 4 feet above the ground. The instruments were checked for eurrent temperature 
weekly, and before beginning the observations they were adjusted so that the average error on extreme temperatures was less than $1^{\circ}$. Thermometers were not available for checking the maximum and minimum temperatures during the period of observation; but in order to neutralize the effect of such errors, the thermographs at the two stations were exchanged in the middle of the period. Thus, while the actual extreme temperatures are probably slightly in error, the comparison between the stations is believed to be reasonably accurate. The results of the observations are given in Table 3.

TABLE 3.-Temperature in a virgin forest and on denuded lands.

\begin{tabular}{|c|c|c|c|c|c|c|}
\hline \multirow{2}{*}{ Month. } & \multicolumn{2}{|c|}{ Mean maximum. } & \multicolumn{2}{|c|}{ Mean minimum. } & \multicolumn{2}{|c|}{ Mean. } \\
\hline & Forest. & Cut-over. & Forest. & Cut-over. & Forest. & Cut-over. \\
\hline $\begin{array}{l}\text { October } \\
\text { November } \\
\text { December........................ }\end{array}$ & $\begin{array}{l}{ }^{\circ} F . \\
63.1 \\
55.4 \\
51.2\end{array}$ & $\begin{array}{l}{ }^{\circ} \mathrm{F} \\
61.0 \\
55.9 \\
51.0\end{array}$ & $\begin{array}{l}{ }^{\circ} F \\
31.4 \\
25.3 \\
23.3\end{array}$ & \begin{tabular}{l|}
$\circ F$ \\
28.3 \\
23.3 \\
21.2
\end{tabular} & $\begin{array}{l}{ }^{\circ} F \\
47.2 \\
40.4 \\
37.2\end{array}$ & $\begin{array}{l}{ }^{\circ} F_{46.1} \\
46.1 \\
39.6 \\
36.1\end{array}$ \\
\hline
\end{tabular}

The results show the same general relation between forest and cut-over area as between forest and park at Fort Valley; but the difference between the minimum temperatures at the stations south of Flagstaff is much less than at Fort Valley. The excess of the mean minimum temperature in the forest over that on the cut-over area, amounting to an average of $2.1^{\circ}$ for the three months, undoubtedly expresses the influence of the forest in checking radiation. The smallness of this effect, compared with the results at Fort Valley, indicates that there is a drainage of cold air into the park at Fort Valley. But, since the immediately surrounding forest is decidedly below the country back of it and only a few feet above the park, it seems that any cold-air drainage from the surrounding mountains and mesas should make itself felt at the forest as well as at the park stations. All of the stations, both in the forest and in the park, are situated on slight rises above the immediately surrounding country, and therefore they should not be subject to local gatherings of cold air. This points to the existence of still other factors.

One explanation of these conditions lies in the possible mechanical resistance offered by the forest to the atmospheric drainage from the surrounding mountains and mesas. The cold air of the mountain slopes would naturally settle into the valley below, thereby causing a general movement toward the park. This air in passing over a timbered area might be prevented to a certain extent by contact with the tree crowns from mixing freely with the warmer air below, and thus be diverted over the tree tops into the open park. In order to determine whether the tree crowns exert any appreciable influence in retarding the diffusion of the cold air into the lower strata of the forest cover, it would be necessary o secure observations on temperature at different heights in and above the forest

Whatever may prove the correct explanation of the relation between forest and park temperatures in this locality, it will probably be found that a considerable influence is exerted by the surrounding mountains and high mesas in the drainage of cold air into the park. 'The importance of the effect of this factor in the forest, however, is probably mitigated by the forest canopy in diverting the cold-air currents. Moreover, the existence of these factors does not render the conditions in the
Fort Valley park very abnormal for this region because numerous mountains, though of less height than the San Francisco Mountains, are scattered over the whole forest, and the parks are almost invariably lower than the surrounding timbered areas. ${ }^{2}$ It is therefore probable that the investigation of other parks in this region would give results very similar to those here recorded.

Probably the best way to determine absolutely whether the presence of the trees is responsible for the milder temperature on the forest area would be to clearcut a portion of the forest and compare the temperature relations between a station on this area and the present forest and park stations before and after cutting. The expense of such a clearing would not be justified at the present tjme. It is therefore the plan to wait until the area is eut by the lumberman. The southwest quarter of the section on which forest station No. 3 is located is owned by private interests and will probably be logged within 10 years. A station has recently been established well within the boundaries of this quarter section and about one-half mile from forest station No. 3. Observations will be continued at this and the other stations through the present year, after which they will be temporarily discontinued, except at the permanent forest station. When cutting is anticipated the observations at the temporary forest station and park station No. 2 will be resumed with the purpose of securing rocords for a year immediately before and after cutting.

\section{SOIL TEMPERATURE.}

Soil temperatures have been measured in the park for a short period only.. Table 4 gives a comparison between the forest and the park temperatures at a depth of 2 feet from July 1 to October 30,1911 .

TABLE 4.-Soil temperature in forest and park.

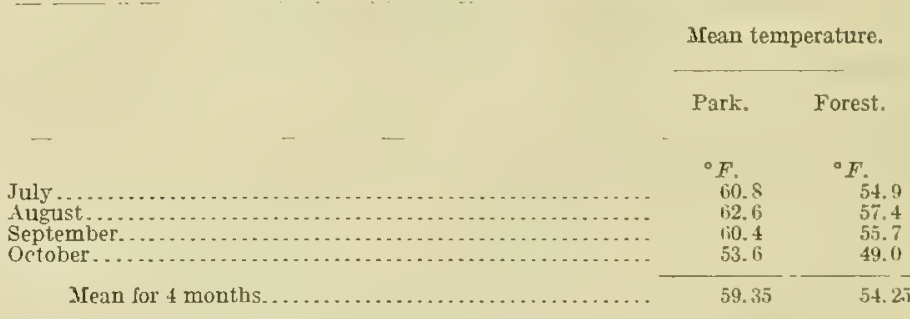

The readings were taken between 8 and 9 o'clock a. 111 . The thermometer in the forest was located on the north side of a group of trees, and therefore represents the lowest rather than the average temperature in the forest. The results show very strikingly the effect of the trees in cutting off the direct sun's rays from the ground beneath them. If the forest canopy were continuous, we should expect the same effect all over the forest floor. Undoubtedly the cooling effect may be ascribed partly to the leaf litter, which acts as an insulator. No data comparing forest and park soil temperatures during the winter months are available; but a comparison of the depth of frozen soil is significant. On the afternoon of February 18,1913 , holes were dug in the middle of an opening and on the north and south sides of a group of trees. The sun was warm, and all the snow had melted on the south side and underneath the trees; but on the north side and in the opening the snow lay from 6 to 8 inches deep. In the opening the soil was frozen from the surface to a depth

${ }^{2}$ This does not apply to the large open areas known as prairies. 
of 23 inches. On the north side of the trees it was frozen from the surface to a depth of $13 \frac{1}{2}$ inches. On the south side every trace of frost had disappeared. The comparatively shallow depth of the frost on the north side is probably due to the protection of deep litter, which at this point was about 2 inches. The presence of tree roots may also be a factor worth considering. On the same afternoon the soil in the park was found to be frozen from the surface to a depth of 29 inches.

According to Nisbet, ${ }^{1}$ European observations have shown that the mean annual temperature of the soil is at all depths of observation, extending down to 4 feet, cooler in the forest than in the open, and that this difference is greatest in summer and least in winter. The mean annual difference at a depth of 2 feet is $1.9^{\circ} \mathrm{F}$. in Prussia, $3.5^{\circ}$ in Bavaria, and $3.2^{\circ}$ in Wurttemberg.

\section{PRECIPITATION}

The mean monthly and total precipitation in forest and park during the four years 1909-1912 is given in Table 5. The yearly distribution is graphically represented in figure 8.

TABLE 5.-Precipitation in forest and park.

\begin{tabular}{|c|c|c|c|c|c|}
\hline \multirow{2}{*}{ Mean, 1909-1912. } & \multicolumn{2}{|c|}{ Precipitation. } & \multirow{2}{*}{ Mean, 1909-1912. } & \multicolumn{2}{|c|}{ Precipitation. } \\
\hline & Park. & Forest. & & Park. & Forest. \\
\hline $\begin{array}{l}\text { January ......... } \\
\text { February...... } \\
\text { March......... } \\
\text { April.......... }\end{array}$ & $\begin{array}{r}\text { Inches, } \\
2.30 \\
1.69 \\
3.27 \\
0.74 \\
0.25\end{array}$ & $\begin{array}{r}\text { Inches. } \\
\text { 2. } \\
1.61 \\
3.49 \\
0.67 \\
0.21\end{array}$ & $\begin{array}{l}\text { September........... } \\
\text { October ............... } \\
\text { November........... } \\
\text { December............ }\end{array}$ & $\begin{array}{r}\text { Inches. } \\
1.26 \\
1.94 \\
0.71 \\
1.51\end{array}$ & $\begin{array}{r}\text { Inches. } \\
1.43 \\
1.92 \\
0.69 \\
1.48\end{array}$ \\
\hline $\begin{array}{l}\text { Jume.... } \\
\text { July... } \\
\text { Jugt }\end{array}$ & 0. 41 & 0. 0.45 & $\begin{array}{l}\text { Total... } \\
\text { Nov. } 1-\mathrm{Apr} .30\end{array}$ & $\begin{array}{l}20.19 \\
10.22\end{array}$ & $\begin{array}{l}20.81 \\
10.08 \\
70.73\end{array}$ \\
\hline August. & 3. 00 & 3.18 & May 1 -Oet. $31 . .$. & 9.97 & 10.73 \\
\hline
\end{tabular}

A comparison of precipitation records in forest and park is of value only in so far as it indicates the influence of the forest canopy upon the normal descent of rain and snow to the ground. The records show, as a rule, a slight excess of rain in the forest during the summer time, and a smaller excess of snow in the park during the winter time. The apparent excess in the forest during the summer months is generally due to the fact that the rain gage in the forest, being sheltered from the wind, receives more nearly the total precipitation than does the gage exposed to the wind in the park. Moreover, the rain gage in the forest, being stationed in an opening, undoubtedly registers a heavier rainfall than would be the case if proper representations were given to the areas under the tree crowns. In other words, the present rainfall records for the forest are too high. The slight excess of snow shown in the park during the winter months is actual. Snowfait is measured by taling the average depth on the ground under the trees as well as in the openings, and since more or less snow is intercepted by the tree crowns, the total amount reaching the ground in the forest is usually somewhat less than in the park. Although the actual precipitation, especially in the time of thunderstorms, may vary considerably between the forest and park stations for individual storms, these

'The Forester, vol. 1 ,p. 71 . differences are usually equalized during a season; and while the yearly records show a small difference, it is doubtful whether there is anv actual difference in the amount of rain which falls from the sky over the forest and the park during a long period of years.

Some idea of the influence of the tree crowns in intercepting rain was gained by placing one rain gage under a group of trees and another in a near-by opening during the month of August, 1909, when the rainfall was exceptionally heavy. The results show a total of 5.74 inches in the opening against 3.44 inches under the trees. Hence the tree crowns intercepted 40 per cent of the rain which fell on them. Undoubtedly a considerable portion of the water intercepted by the trees drains off, falling on the ground underneath the outer portion of the crowns and causing an excess here, which in part makes up for the deficit directly under the trees. But it stands to reason that for a given rainfall the total amount of water reaching the ground on a given area in a forest is less than what would reach the ground on the same area if the trees or other vegetation were absent.

Observations on snowfall show that a large amount of snow is collected by the tree crowns, especially in still weather and when the snow is moist. Usually the bulk of this snow is blown off and deposited in the near-by openings, while the remainder melts and reaches the ground in the form of water, or is lost by evaporation. As a result of these conditions the snow is usually much deeper in the small openings than directly under the tree groups. After several days of melting it is common to find the ground under the trees entirely bare (see fig. 9), while in the neighboring small openings it is from 2 to 3 feet deep. Usually the average depth of snow in the forest is somewhat less than in the park during the winter because of the more rapid melting resulting from the higher temperature in the forest: but systematis observations during four years show that in the spring banks of snow remain in the forest from two to three weeks after all traces have disappeared from the park.

There is also a noticeable difference in the amonnt of run-off. While no actual measurements of run-off' have been made, general observations show bevond any doubt that the per cent of run-off is greater in the park than in the forest. The park soil, as well as that in the openings of the forest, remains frozen to a depth of 2 feet or more through the winter, with the result that it is in a poor condition for absorbing moisture; but under the trees, particularly on the south side, the ground is of ten fornd entirely free of frost in midwinter. As the snow melts on these spots, it is completely absorbed by the soil and leaf litter. Not only this, but the water from melting snow banks in adjoining openings where the ground is frozen runs into these spots and is largely absorbed, thus forming veritable reservoirs. This process was observed to be going on on the 18th of February, 1913, when, though the frost was 23 inches deep in the openings of the forest and 29 inches deep in the park, not a trace was found on the south side of the large tree groups.

\section{ATMOSPHERIC HUMIDITY}

Table 6 gives the mean monthly relative humidity at each station from 1909 to 1912 , inclusive. The same data are represented graphically in figure 8. 
TABLE 6.-Relative humidity.

\begin{tabular}{|c|c|c|c|}
\hline \multirow{2}{*}{ Month (average 1909-1912). } & \multicolumn{3}{|c|}{$\begin{array}{l}\text { Mean relative humidity. } \\
\text { (Per cent.) }\end{array}$} \\
\hline & Forest (3) & $\begin{array}{l}\text { Edge of } \\
\text { forest (1). }\end{array}$ & Park (2). \\
\hline 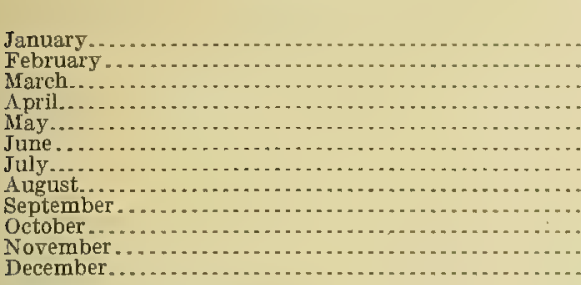 & $\begin{array}{r}\text { Per cent. } \\
68.8 \\
57.8 \\
60.3 \\
47.9 \\
38.0 \\
34.9 \\
59.9 \\
66.3 \\
52.7 \\
52.6 \\
57.3 \\
48.0\end{array}$ & \begin{tabular}{|r} 
Per cent. \\
71.3 \\
65.3 \\
65.4 \\
45.5 \\
30.4 \\
29.1 \\
52.8 \\
57.8 \\
48.8 \\
51.2 \\
58.9 \\
44.8
\end{tabular} & $\begin{array}{r}\text { Per cent. } \\
69.3 \\
64.9 \\
66.5 \\
45.6 \\
33.9 \\
33.9 \\
56.3 \\
61.6 \\
50.3 \\
53.8 \\
61.1 \\
54.1\end{array}$ \\
\hline $\begin{array}{l}\text { Mean Jan. 1-Dec. } 31.0 . \\
\text { Mean Nov. 1-Apr. } 30 . \\
\text { Mean May 1-Oct. } 31 .\end{array}$ & $\begin{array}{l}53.7 \\
56.7 \\
50.7\end{array}$ & $\begin{array}{l}51.8 \\
58.5 \\
45.0\end{array}$ & $\begin{array}{l}54.3 \\
60.2 \\
48.3\end{array}$ \\
\hline
\end{tabular}

The annual means at the three stations do not show a sufficient difference to warrant any conclusion with respect to difference between forest and park.
The records indicate a lower relative humidity in the forest than in the park during the winter, and the reverse relation during the summer. Since humidity readings have been taken only once per day and not simultaneously at the three stations the data at hand are considered inadequate to furnish a reliable comparison between the forest and the park. Such comparisons of absolute humidity as have been made show a small difference in favor of the forest; but, as in the case of relative humidity, the difference is too small to warrant any conclusions. An adequate study of atmospheric moisture would require several readings during both day and night, or else the use of self-recording instruments. With respect to absolute humidity the results of all observations made fail to show any marked or constant difference between the forest and the open.

WIND.

Table 7 gives the mean daily wind movement by months in the forest, the edge of the forest, and the park during the four vears from 1909 to 1912 inclusive. A graphic comparison of the forest and the park is given in figure 8 .

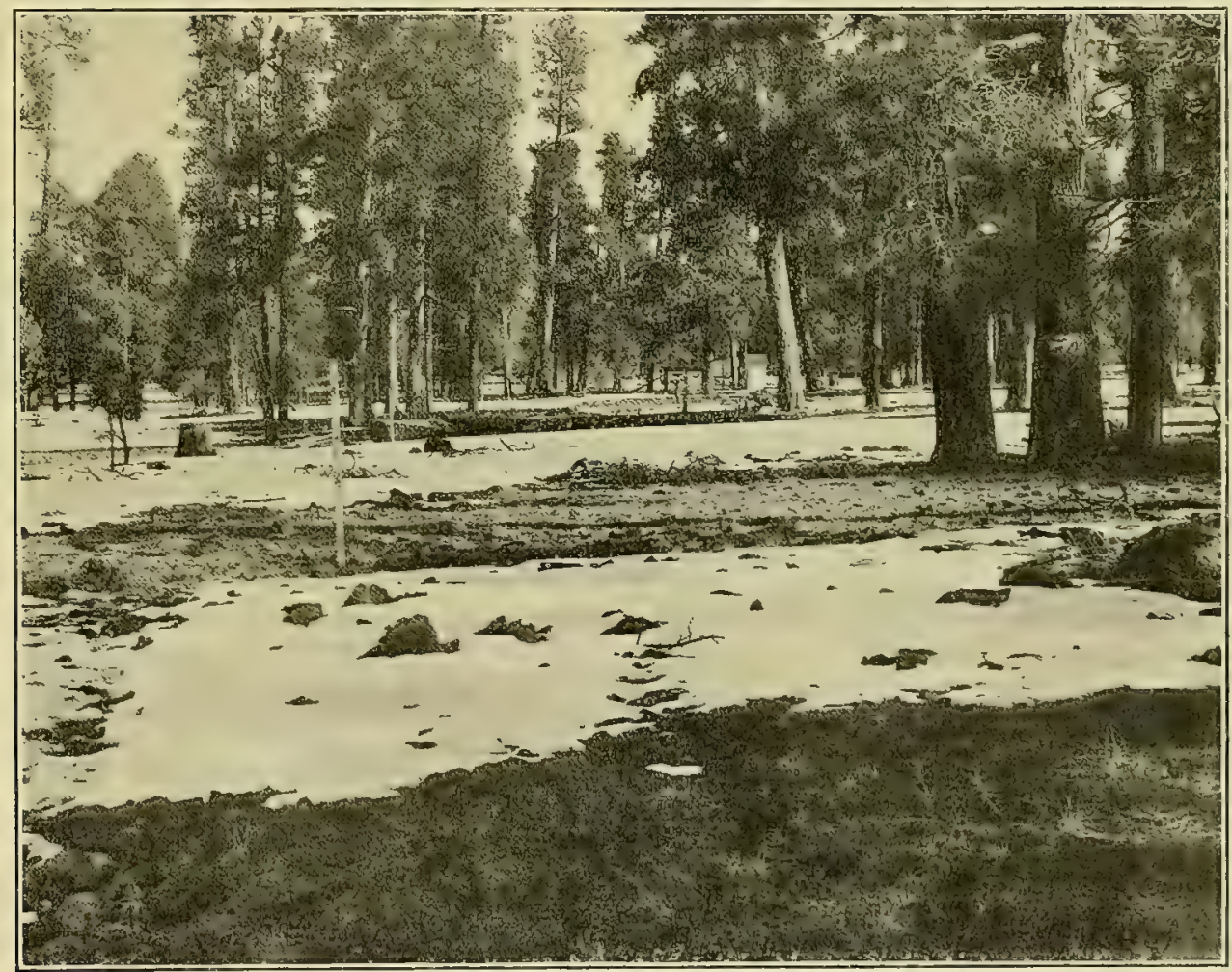

Frg. 9.-Distribution of snow in the forest. Note bare ground under trees (looking north).

TABLE 7-Wind movement in forest, at edge of forest, and in park.

\begin{tabular}{|c|c|c|c|c|c|c|c|}
\hline \multirow{2}{*}{$\begin{array}{l}\text { Average } 1909- \\
\quad \text { I912. }\end{array}$} & \multicolumn{3}{|c|}{$\begin{array}{l}\text { Mean dailly wind move- } \\
\text { ment. }\end{array}$} & \multirow{2}{*}{$\begin{array}{l}\text { Average 1909- } \\
1912 .\end{array}$} & \multicolumn{3}{|c|}{$\begin{array}{l}\text { Mean daily wind move- } \\
\text { ment. }\end{array}$} \\
\hline & $\begin{array}{l}\text { Forest } \\
\text { (3). }\end{array}$ & $\begin{array}{l}\text { Edge of } \\
\text { forest } \\
\text { (1) }\end{array}$ & $\begin{array}{c}\text { Park } \\
(2) .\end{array}$ & & $\begin{array}{l}\text { Forest } \\
\text { (3). }\end{array}$ & $\begin{array}{c}\text { Edge of } \\
\text { forest } \\
(b) .\end{array}$ & $\begin{array}{l}\text { Park } \\
(2) .\end{array}$ \\
\hline a & $\begin{array}{r}\text { Miles. } \\
56.5\end{array}$ & $\begin{array}{l}\text { Afiles. } \\
193.2\end{array}$ & $\begin{array}{l}\text { Mriles: } \\
107.3\end{array}$ & July.... & $\begin{array}{l}\text { Miles. } \\
50.5\end{array}$ & $\begin{array}{r}\text { Miles. } \\
98.7\end{array}$ & $\begin{array}{l}\text { Miles. } \\
106.8\end{array}$ \\
\hline & $\begin{array}{r}66.9 \\
68\end{array}$ & 111.1 & 126.5 & August .. & $\begin{array}{l}49.0 \\
58.9\end{array}$ & $\begin{array}{r}84.9 \\
10.3\end{array}$ & $\begin{array}{r}86.8 \\
107.0\end{array}$ \\
\hline & $\begin{array}{l}68.2 \\
80.6\end{array}$ & $\begin{array}{l}121.1 \\
150\end{array}$ & $\begin{array}{l}130.8 \\
158.7\end{array}$ & $\begin{array}{l}\text { September } \\
\text { October }\end{array}$ & 59.2 & $\begin{array}{l}100.0 \\
117.2\end{array}$ & 118.0 \\
\hline $\begin{array}{l}\text { May. } \\
\text { May. }\end{array}$ & $\begin{array}{l}80.0 \\
84.9\end{array}$ & $\begin{array}{l}160.0 \\
167.2\end{array}$ & $\begin{array}{l}108 \\
174\end{array}$ & November. & 59.8 & 1113.5 & 111. 6 \\
\hline & 76.5 & 150.0 & 151.9 & December.. & 56.2 & 95.2 & 105.8 \\
\hline
\end{tabular}

The wind movement is about twice as great in the park as in the forest. This difference is in accord with results obtained at European stations. The protective influence of the timber is undoubtedly the only important factor to be considered in accounting for this difference between forest and park conditions.

The wind movement at station 1, in the edge of the forest, is but slightly less than that at station 2 in the park. The smallness of this difference is due to the fact that station 1, while protected on the west and northwest sides, receives practically the full force of the wind from other directions, especially the southwest, whence come the prevailing winds of this region. 
EVAPORATION.

Table 8 gives the monthly evaporation in the forest and the edge of the forest from 1909 to 1912 inclusive. A graphic comparison of the two stations is given in figure 8 . Since the evaporation pans would freeze solid in the winter time, measurements have been made only during the growing season, from May 1 to October 31. In 1909, the measurements were not begun until July 1, and therefore the monthly means for May and June represent only three years.

TABLE 8.-Evaporation in and at edge of forest.

\begin{tabular}{|c|c|c|c|c|c|}
\hline \multirow{2}{*}{ Average, $1909-1912}$. & \multicolumn{2}{|c|}{ Total evaporation. } & \multirow[b]{2}{*}{ A verage, 1909-1912. } & \multicolumn{2}{|c|}{ Total evaporation. } \\
\hline & $\begin{array}{l}\text { Forest } \\
\text { (3). }\end{array}$ & $\begin{array}{l}\text { Edge of } \\
\text { forest }(1) \text {. }\end{array}$ & & $\begin{array}{c}\text { Forest } \\
(3) .\end{array}$ & $\begin{array}{l}\text { Edge of } \\
\text { forest (1). }\end{array}$ \\
\hline $\begin{array}{l}\text { May } \\
\text { June................... } \\
\text { July ... }\end{array}$ & $\begin{array}{r}\text { Inches. } 1 \\
5.8 \\
7.3 \\
5.5\end{array}$ & $\begin{array}{r}\text { Inches. } 1 \\
8.8 \\
10.9 \\
7.5\end{array}$ & $\begin{array}{l}\text { September.......... } \\
\text { October........... }\end{array}$ & $\begin{array}{r}\text { Inches. }{ }^{1} \\
4.2 \\
3.2\end{array}$ & $\begin{array}{r}\text { Inches. }^{1} \\
6.1 \\
4.4\end{array}$ \\
\hline August...................... & 4,8 & 6.1 & Total. & 30.8 & 43.8 \\
\hline
\end{tabular}

The factor mainly responsible for the decreased evaporation in the forest at this station is probably the decreased wind movement. Other factors affecting evaporation are atmospheric moisture and temperature. The records show a slightly higher relative humidity in the forest than in the park during the period when evaporation is measured; but, as already stated, the data on atmospheric moisture are inadequate for an accurate comparison of forest and park conditions. The higher temperature in the forest would tend to increase the evaporation, but since this occurs mainly at night when the atmosphere is comparatively near the saturation point, its influence is more than offset by the lower wind movement.

An examination of figure 8 shows that the evaporation is the greatest during the months of May and June, which are also the months of greatest wind movement, lowest relative humidity, and lowest precipitation. In July and August, although the temperature is higher than in the preceding months, the evaporation is lower on account of lower wind movement and the higher relative humidity and precipitation. Since the summer rains usually do not begin until about July 15, the records during the first half of the month are much higher than during the latter half. The low evaporation in September and October is due mainly to a decrease in temperature, since wind and relative humidity during these months are favorable for high evaporation.

The evaporation in the forest during the growing season is only 70 per cent of that at the edge of the forest. Evaporation was measured in the park (station 2) only during a period of four months in 1909. During this time the record was slightly below that at the edge of the forest. Since the two stations are so nearly alike with respect to temperature and wind exposure, the record at the edge of the forest is considered representative of the park.

German observations ${ }^{1}$ at 17 stations for 10 years show the evaporation from a free water surface in the forest from May 1 to October 31 to be approximately 40 per cent of that in the open. The great reduction of evaporation in the German forests as compared with our yellow-pine forests is explained by the greater density of the

1 M. W. Harrington, Forest Service Bulletin No. 7, part 2, p. 97. furmer. A further explanation is found in the fact that at the German stations the mean temperature in the forest is lower than that in the open, while here it is higher.

The decrease of evaporation in the forest may be regarded as expressing the sum total of the forest's influence upon wind, relative humidity, and to a less extent of solar radiation. The latter factor is expressed only in a minor degree, because the evaporation pan in the forest is stationed in an opening where it is shaded by the trees only during a few hours of the day, and not at all when the sun is at its height.

\section{SUMMARY OF RESULTS OF METEOROLOGICAL STUDY.}

The records show that the mean annual temperature in the forest is $2.7^{\circ}$ higher than in the park. The most important difference, however, is in the extreme temperatures. 'The maximum averages $0.9^{\circ}$ lower, and the minimum $6.4^{\circ}$ higher in the forest than in the park. The mean daily range is $7.3^{\circ}$ smaller in the forest.

The evidence at hand supports the opinion that the above relation is due to the influence of the forest canopy. The influence upon minimum temperatures, which is by far the greatest and most important, appears to be exercised partly by the action of the tree crowns in checking the loss of heat by radiation, but mainly by the deflection of cold air currents from surrounding mountains and high mesas. A final and absolute determination of the extent to which the presence of trees is responsible for the amelioration of temperature conditions in the forest, and the determination of the manner in which its influence is exerted demands further investigation.

The temperature of the soil in the forest during the summer, when shaded by trees, is about $5^{\circ}$ lower at a depth of 2 feet than at the same depth in the park.

The available data on atmospheric humidity show no definite relations between forest and park, excepting that the relative humidity appears to be slightly higher in the forest during the summer time and slightly higher in the park during the winter time.

The only appreciable effect of the forest upon precipitation is in its influence upon the distribution and disposal of snow and rain. Considerable amounts of snow and rain are collected by the tree crowns. Probably the greater portion of this blows or drips off, but an appreciable amount is lost by evaporation. The snow falls more evenly and accumulates to a slightly greater depth in the park than in the forest in the winter time, but it remains on the ground from two to three weeks later in the forest. A greater proportion of the snow waters is absorbed by the soil in the forest than in the park.

The average wind movement is only 51 per cent as great in the forest as in the park.

The evaporation from a free water surface is only 70 per cent as great in the forest as in the park.

The influence of the forest upon all factors studied, with the exception of relative humidity for which our data are inadequate, is similar to that shown by European observations. In the European forests, as in those covered by this study, the extremes of temperature are modified; but in European forests the maxima are lowered more than the minima are raised, with the result that the mean temperature is lower in the forest than in the open, while in our forests the maxima are lowered less than the minima are raised, with the result that the mean temperature is higher in the forest than in the open. The influence of the forest in decreasing evaporation is 30 per cent greater in Europe than is shown in this study. 
SILVICULTURAL APPLICATION OF THE METEOROLOGICAL DATA.

From the first introduction of scientific forestry in this region it has been recognized that climatic conditions of unusual severity must be dealt with. The problem of reproduction has been and will continue to be the greatest silvicultural problem in the management of our western yellow-pine stands, which constitute 95 per cent of the timber forest in Arizona and New Mexico. Recognizing these conditions, a shelter-wood system of cutting, in which a portion of the original stand is left not only for the production of seed, but also as a protection to young growth, has been used since the forests came under the administration of the Forest Service. This investigation shows that extremely adverse climatic conditions exist, that a forest cover exercises a profound influence in ameliorating these conditions, and that the reasons for adopting a shelter-wood system are well founded.

\section{FORESTATION OF PARKS.}

As regards parks, this study indicates that climatic conditions on such areas are decidedly unfavorable to the establishment of forest growth; that the invasion of such areas by forest trees can as a rule not be expected, and that if their afforestation is ever accomplished it must be by artificial means.

It is believed that atmospheric conditions in the Fort Valley Park are fairly representative of other parks in the region. With respect to wind and consequent evaporation there can be no great difference. In larger parks these factors will be higher and in smaller parks lower than at Fort Valley. They will also vary with the location in the park, the lowest wind and evaporation being found along the south and west borders, since the prevailing winds are from the southwest. We might expect a great variation with respect to minimum temperature, but since nearly all parks are so situated as to receive cold-air drainage from the surrounding country, very low minimum temperatures resulting from this cause as well as from radiation may be looked for. On prairies, which are on the same level as the surrounding timbered country and are thus exempt from cold-air drainage, the only reduction of minima would be that due to radiation, and here we may expect to find about the same temperature conditions as on the cut-over area described on pp. 16221623, namely, a slight increase of the maxima and a reduction of the minima by $2^{\circ}$ or $3^{\circ}$ as compared with the forest.

The action of drought, through excessive evaporation from the soil and from the plant itself, and of low temperature in the form of unseasonable frosts, is very destructive to young seedlings before they have developed deep-root systems and woody stems. Annual observations on marked plots on the Coconino and Apache ${ }^{1}$ National Forests show that even under the partial protection afforded on cut-over lands over 95 per cent of the seedlings die during the first year. The loss among seedlings which might spring up in a park under full exposure to the wind and frosts can only be conjectured.

A practical demonstration of the protective influence of the forest upon the action of wind and evaporation is afforded by a planting experiment in the spring of 1909 . Fifty 2-year-old western yellow-pine transplants were planted on April 22 under sumilar conditions at station 1 on edge of the forest, where wind and evaporation are practically the same as in the park, and at station 2 in the forest. Western yellow pine at this age is not very

1 Forest Service Bulletin 125, pp. 23-28. susceptible to frost, and therefore the losses are attributable to other causes. On May 21 only 11 per cent of the plants at station 1 were alive, while at station 3,90 per cent were alive. Soil samples taken on May 21, however, showed a moisture content of 17 per cent at station 3 , and 17.5 per cent at station 1 , in the zone occupied by the roots, which were about 8 inches long. The moisture content is abundant for pine seedlings on both soils under reasonably favorable atmospheric conditions. No evaporation records are available for this period, but the wind movement at the edge of the forest was almost twice as great as in the forest. The conclusion is therefore that the plants in the edge of the forest, with an abundant water supply at their roots, dried up simply because the water loss from the foliage exceeded the amount supplied by the roots. In the forest, on account of a lower rate of evaporation from the foliage, a safe balance between the supply and expenditure of water was maintained.

As a result of the above experience, planting in parks was almost despaired of, but another attempt was made in 1912 with excellent results. This success is attributed entirely to the use of a superior grade of plants. It has been demonstrated that western yellow-pine can be planted successfully in parks if good stock is used; but we have no assurance that plantations will grow to maturity. It is possible that the absence of natural forests in parks may be explained by the presence of adverse atmospheric conditions which make it impossible for seedlings to survive the first year; but it is probable that there are also other factors, such as unfavorable soil conditions. The bulk of our park areas in the yellow-pine type will eventually be given over to agriculture; but such portions as are too rocky for farming should be forested if possible.

\section{FOREST NURSERIES.}

The nursery of the Fort Valley Experiment Station is at present located at the edge of the forest. It is protected from southwest winds, but temperature conditions approach those of the park. The site has proven an excellent one for western yellow-pine; but Douglas fir, Jeffrey pine, Austrian pine, European and Siberian larch, and several other exotics have suffered severely from winter killing. A small Douglas fir nursery has been established in the forest, where it grows naturally. Should any of the other species prove desirable for planting, nursery stock could undoubtedly be produced more successfully in the forest, where it will be less exposed to frost.

\section{REPRODUCTION AFTER CUTTING.}

The park and virgin forest represent the two extremes of exposure and protection. Conditions on cut-over lands are intermediate between the above extremes. Moreover, it should always be borne in mind that conditions on any area vary with the degree of cutting, topography, and other local factors. It is believed that the relation between park and forest at Fort Valley will be found to hold; in a general way, for the whole Southwest; but we should not be surprised to find considerable modifications of this relation in one direction or another in different localities.

The primary object in seeking to take advantage of the protection afforded by the forest is to secure natural reproduction. If planting were resorted to, it is possible that there would be no need for leaving trees to furnish protection for young growth. But since planting does not promise to become economically practicable under general conditions, natural reproduction must be the 
first consideration in any silvicultural system which we may adopt.

Areas which have been logged-over approach the state of parks in proportion to the degree of cutting, with this difference, that cut-over areas, unless, like the parks, they lie below the surrounding country, are less subject to unseasonable frosts. Excepting in valleys which receive cold-air drainage, the difference in minimum temperatures on heavy and light cuttings, judging from the relation between virgin forest and clearcutting described on pages 1622-1623, probably does not ordinarily exceed one or two degrees. But we may always expect a very pronounced difference with respect to wind movement, particularly on long stretches of comparatively level country. A comparison of the wind movement on a cut-over area at Fort Valley, from which approximately two-thirds of the original stand has been removed, with the virgin forest and the park from June 12 to July 12, 1910, showed the following average daily wind movements: Forest, 73.3 miles; cut-over area, 86.6 miles; park, 140.2 miles. In regions of rough topography little concern need be felt for the effects of wind in narrow valleys and on north slopes; but on exposed ridges and south slopes exposure to both wind and sun must be rigidly guarded against. Valleys, while protected from wind, are more or less subject to frost, and if there is any evidence of frost injury heavy cutting should be avoided.

Generally, young growth established under the protection of older trees is often not considered safe from climatic injury even after it is 5 or 6 years old. This applies particularly where the sudden removal of the cover is involved. This danger is indicated by an experiment on the Coconino National Forest.

On a section near Flagstaff where about two-thirds of the stand was cut 27 years ago, a considerable amount of young growth came in from 4 to 8 years ago. In order to observe the progress of reproduction, two permanent sample plots were established on the area in 1908, the seedlings being then from 2 to 4 years old. A plot was also established in a neighboring virgin stand. Counts from 1908 to 1911 showed the following losses from year to year:

TABLE 9.-Loss of seedlings for period of three years.

\begin{tabular}{l}
\hline \\
19
\end{tabular}$\ldots$

In the summer of 1911 the area was logged a second time, removing the entire stand. In the summer of 1912, when the area was examined again, it was found that a large number of seedlings were dead or dying. Since the plots were distributed in the logging operations the percentage of loss from 1911 to 1912 could not be accurately determined, but it was possible to get a conservative figure from the actual number of dead seedlings found. In order to secure more representative conditions, additional plots were examined. Counts showed that out of 700 seedlings from 5 to 8 years old, 23 per cent were dead and 13 per cent doubtful. Additional plots were also laid out in the forest which had not been disturbed by cutting. Out of 600 seedlings on these plots only 6 per cent were dead and 2 per cent doubtful. The heavy loss on the logged area (it is safe to count 10 per cent of the doubtful seedlings as dead) is undoubtedly due to the effect of the sudden exposure incident to heary cutting.

The idea of supplementing the protection afforded by standing trees by scattering branches cut from felled trees upon the ground has been suggested and has many adherents. Experiments ${ }^{1}$ have shown that a brush cover increases the temperature by two or three degrees on cold, clear nights, and that it is effective, within certain limits, in saving seedlings from frost damage. Observations also show that a brush cover exercises an appreciable influence in preserving soil moisture, although this effect disappears after protracted periods of drought. Despite thess influences, annual observations on an area of 125 acres on which brush was scattered after logging in 1908 show a-greater loss of seedlings and a smaller number remaining at the present time under brush than on adjoining open spots. This result may be partially explained by the fact that many of the seedlings which come up under the brush receive too little sunlight, and the fact that after the first year the needles drop off, forming a litter upon the ground which makes it impossible for seeds to reach the mineral soil. But the effect of a brush cover is far-reaching, and a number of years must elapse before it can be definitely determined what the net result will be. As the leaf litter decays it will jmprove the soil, while the coarser branches will form a light screen, though not casting an excessive amount of shade. On the other hand, the dry needles and branches are always a fire menace which may cause the destruction of an entire crop of seedlings.

A proposed modification of the brush cover, which aims to secure a large share of the advantages without the attendant disadvantages, is to scatter large branches rather thinly upon the ground, so that clear spaces a foot or two in diameter will intervene. Conditions directly underneath the branches will be the same as described above; but seeds falling in the open spots will come in contact with the mineral soil, and the seedlings while enjoying sufficient sunlight will receive a considerable amount of wind protection. The fire danger is decreased but not eliminated.

Another method is to leave the tops practically undisturbed after removing the merchantable logs from the felled trees. Due precaution being taken not to leave tops where they will constitute a fire menace to existing advance growth, the prostrate trunk with its projecting branches thus forms a sun shield and wind break for seedlings which spring up underneath and on the sheltered side. This practice is the one followed on all the old cuttings under private control, with the exception that in such cuttings no attention was paid to fire danger. Many instances have been found where good reproduction has succeeded these cuttings, and not infrequently it is confined almost entirely to rows of saplings along old tree trunks. There are, however, plenty of instances where practically no young growth has started on old cuttings, not even along the tops. Among the factors which may be responsible for this condition are fires, the destruction of seed by rodents, or, in the case of heavy cuttings, absolute lack of seed. The main advantage of this method over scattering the branches is that of economy, since the only cost is that of pulling an occasional top away from a standing tree or group of saplings, while the cost of scattering the branches amounts to 
about 40 cents per thousand board feet of timber cut. The protective influence under this method is concentrated on limited strips along each tree top, while, where the branches are cut off and scattered, their influence is spread over a larger area.

The shelter necessary to insure conditions favorable for natural regeneration is not usually secured without a sacrifice of merchantable timber. The least difficult stands to regenerate are those having a large percentage of immature trees at the time of cutting. Under the present system of cutting, it is the aim to return in approximately 40 years and remove the then mature trees which at the time of the first cutting were left for the purpose of reproduction. It is also the aim to leave enough trees so that the yield at the time of the second cut will warrant the expense of logging. Usually about one-third of the stand, or from 2,000 to 3,000 board feet per acre, is left. If this timber consists of immature growing trees they can be left at a profit. Occasionally there are enough such trees in a stand to provide for reproduction, and then the cost of regeneration is nil. But often we have the other extreme in which the stand is made up almost entirely of mature and overmature trees which would yield the greatest return if cut now. If we leave a sufficient number of such trees to furnish the seed and protection required for reproduction, a certain amount of deterioration will take place before the second cutting can be executed, and the financial loss through this deterioration must be charged agninst the cost of regeneration. Usually we find the intermediate condition where there are a sufficient number of immature, or at least sound and thrifty trees, so that it is necessary to leave only a few mature trees of high merchantable value. However, whenever it is necessary to leave a tree which at the time of the second cut will not yield a net return equal to its present value, considering growth or déterioration, increase in stumpage price, and interest on the capital, that tree is left at a financial loss.

In cutting stands in which, to satisfy the requirements for natural reproduction, it becomes necessary to leave a large volume of mature timber, the old question arises, "Will the service rendered by these trees through the production of seed and protection to young growth offset the loss which will be incurred through their deterioration?" and "Would it not be more economical to cut these trees and regenerate the area by planting?" Considering the care required in planting western yellowpine in this region, the cost per acre can probably not be reduced below $\$ 12$. If in cutting it is found necessary to leave four mature trees per acre, aggregating 3,000 board feet, and it is estimated that one-half of this will be lost before a second cutting is made, the loss, assuming a stumpage value of $\$ 3.50$ per thousand, is $\$ 4.75$. Thus it would be much less expensive to leave the trees than to plant. It often occurs, however, that the ground is already partially stocked, so that it may be necessary to actually plant only one-half or one-fourth acre. If one-half acre is planted the cost will be $\$ 6$, and if only one-fourth acre is planted the cost will be but $\$ 3$. Thus the question must be decided for each area separately, considering the probable loss in timber and the cost of planting upon the basis of the actual area it will be necessary to plant. It should also be borne in mind that old trees suppress young growth in their immediate vicinity, so that after they are removed blanks will mark their former position. Furthermore, a certain amount of damage to reproduction will result from logging. Fortunately, the areas on which there is a great risk through deterioration of seed and shelter trees are not extensive. There are areas, however, on which satisfactory reproduction will not be secured even under the best of treatment, and on such areas it will be necessary to plant as a last resort. Furthermore, even on areas where reproduction is generally good, we may expect occasional fail spots where it will be advantageous to plant.

Further investigations on cut-over areas, with special reference to the effect of different degrees of cutting upon physical conditions which are now being conducted by the Fort Valley Forest Experiment Station, will undoubtedly determine with greater scientific certainty how our western yellow-pine forests should be managed. This study merely attempted to lay the scientific foundation upon which to base the broad principle of forest management of western yellow-pine in the Southwest. 





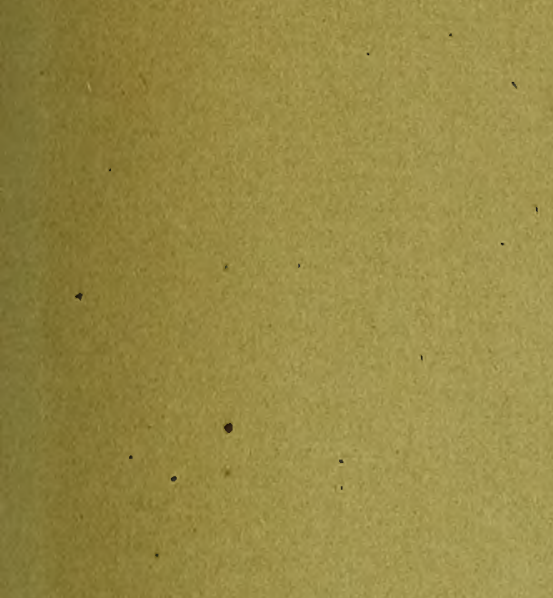


